\title{
Optimization of Osmotic Dehydration Coupled to Hot Air Drying for the Production of Tomato Powder and Reconstituted Concentrates
}

\author{
C. T. Maka, O. R. Isma-ila, J. F. Ekorong Akouan Anta, and C. Kapseu
}

\begin{abstract}
The brine temperature $\left(\mathrm{X}_{1}\right)$, the $\mathrm{NaCl}$ concentration $\left(X_{2}\right)$, the drying temperature $\left(X_{3}\right)$, and the drying time $\left(\mathrm{X}_{4}\right)$ were the 4 parameters explored in this study, which aimed to model the OD-Drying coupling of fresh tomato. A 4 factors Box-Behnken experimental design associated to the response surface methodology (RSM). A transformation of the usual quadratic model was necessary to fit the experimental results. From the obtained models, relationships between the studied factors and the followed responses were establish. From the multicriteria optimization, the following conditions were found as optimal: $X_{1}=65^{\circ} \mathrm{C}, X_{2}=5 \%, X_{3}=43.88{ }^{\circ} \mathrm{C}$ and $X_{4}=$ $24 \mathrm{~h}$. The tomato powder obtained by reproduction of optimal conditions showed better properties than the tomato powder produced by local farmer by sun drying, but similar characteristics as the concentrate prepared from it. From the fresh tomato to the tomato powder obtain using the optimal conditions, the overall quality lost is relatively low.
\end{abstract}

Index Terms - Tomatoes, Osmotic dehydration, Drying, Response Surface Methodology, Colour.

\section{INTRODUCTION}

Tomato (Solanum lycopersicum L.) is a climacteric vegetables world widely cultivated for its multiple use and nutrients richness (lycopene, mineral salts). Tomato has a high-water content and is poor in calories, making it an excellent dietary food. However, that high water content also makes tomato very perishable, justifying the application of different transformation and conservation techniques to fresh tomato. It allows to face the problem of enclaved production areas, imposing constraints on the distribution of fresh products [1]. Drying is one of the techniques used for tomato preservation.

Drying is one of the most commonly used fruits and vegetables conservation techniques [2]. There are several drying methods, as solar drying, convective air drying which is easy to implement compared to more advanced technique like the microwave drying or the freeze-drying. Generally, they present better drying time and provide a final product with a better quality compare to the solar drying [3]. However, the heat exposure during drying leads to some drawbacks like oxidation of certain vitamins and thermo sensitive compounds, with colour degradation, which could

Submitted on June 16, 2021.

Published on July 07, 2021.

C. T. Maka, Department of process engineering, University of Ngaoundéré, Ngaoundéré, Cameroon.

(corresponding author e-mail: makacybele@yahoo.fr)

O. R. Isma-ila, Department of process engineering, University of Ngaoundéré, Ngaoundéré, Cameroon.

(e-mail: ismailaousmanou01@gmail.com) be mitigated by dehydration-impregnation by immersion [1]

Osmotic dehydration can be classified as an improved method of treating food or biologics [4]-[6]. It preserves the colour, taste and flavour of foods intended to be dried. It also significantly reduces drying time and drying energy by partially eliminating water without extensive denaturation of the food's properties [7].

Several works have been done on the drying of the tomato and its optimization [2], [3], [8], as well as the application of osmotic dehydration on tomatoes [1], [6], [9], [10]. But very few researches report the study, the modelling and optimized of both unit operation coupled and applied to tomato. Thus, using the experimental design coupled to the response surface methodology, this work aimed to study the effect of the couple Osmotic dehydration - Drying on some characteristics of the dried tomatoes, and optimize the process.

\section{MATERIAL AND METHODS}

\section{A. Sample Preparation}

Fresh tomatoes, acquired at the Dang market (Ngaoundéré, Cameroon) were sorted, washed with tap water, and wiped. The selected samples, ripe and undamaged tomatoes, were physically characterized (weight, height and diameter) in order to determine the shape coefficient [11] given by the formula:

$\mathrm{C}_{f}=\frac{\text { Height }}{\text { Diameter }}$

$\mathrm{C}_{\mathrm{f}}<0.8$ indicates a flattened shape; $0.8 \leq \mathrm{C}_{\mathrm{f}} \leq 1$ indicates a round shape; $\mathrm{C}_{\mathrm{f}}<1$ indicates an elongated shape. Crosssection slices of $8 \mathrm{~mm}$ were made for the determination of some physicochemical properties. (Residual Water content, total carotenoid content, $\mathrm{pH}$, titratable acidity) and colour characteristics $\left(\mathrm{L}, \mathrm{a}^{*}, \mathrm{~b}^{*}, \mathrm{C}, \mathrm{H}^{\circ}\right)$.

\section{B. Osmotic Dehydration-drying}

Modelling and optimization were done using a 4-factor Box-Behnken design coupled with the response surface methodology (Table I). Box-Behnken experimental design is among the most efficient experimental designs, giving

J. F. Ekorong Akouan Anta, Ghent University Global Campus, Incheon, South Korea, Republic of Korea.

(e-mail: ejfanta7@yahoo.fr)

C. Kapseu, Department of process engineering, University of Ngaoundéré, Ngaoundéré, Cameroon.

(e-mail: kapseu ${ }^{\circledR}$ yahoo.fr) 
optimal conditions in a minimum number of experimental runs and the easiest to set up [12] The studied parameters are the osmotic dehydration water temperature $\left(\mathrm{X}_{1} / \mathrm{T}_{\mathrm{OD}}\right)$ and salt concentration $\left(\mathrm{X}_{2} / \mathrm{C}_{\mathrm{NaCl}}\right)$, and the drying temperature $\left(\mathrm{X}_{3} / \mathrm{T}_{\text {Dry }}\right)$ and time $\left(\mathrm{X}_{4} / \mathrm{t}\right)$.

TABLE I: 4- FACTORS BOX-BEHNKEN EXPERIMENTAL DESIGN AND THE CORRESPONDING EXPERIMENTAL VALUES

\begin{tabular}{|c|c|c|c|c|c|c|c|c|}
\hline & \multicolumn{4}{|c|}{ Osmotic dehydration } & \multicolumn{4}{|c|}{ Drying } \\
\hline Run & $\mathrm{X}_{1}$ & $\begin{array}{l}\mathrm{T}_{\mathrm{OD}} \\
\left({ }^{\circ} \mathrm{C}\right)\end{array}$ & $\mathrm{X}_{2}$ & $\begin{array}{c}\mathrm{C}_{\mathrm{NaCl}} \\
(\%)\end{array}$ & $\mathrm{X}_{3}$ & $\begin{array}{l}\mathrm{T}_{\text {Dry }} \\
\left({ }^{\circ} \mathrm{C}\right)\end{array}$ & $\mathrm{X}_{4}$ & $\begin{array}{c}\mathrm{t} \\
\text { (h) }\end{array}$ \\
\hline 1 & -1 & 25 & 0 & 10 & 0 & 55 & -1 & 6 \\
\hline 2 & -1 & 25 & -1 & 5 & 0 & 55 & 0 & 15 \\
\hline 3 & 0 & 45 & -1 & 5 & 0 & 55 & -1 & 6 \\
\hline 4 & -1 & 25 & 1 & 15 & 0 & 55 & 0 & 15 \\
\hline 5 & 1 & 65 & 0 & 10 & 0 & 55 & -1 & 6 \\
\hline 6 & 0 & 45 & 0 & 10 & 0 & 55 & 0 & 15 \\
\hline 7 & 0 & 45 & 1 & 15 & 0 & 55 & -1 & 6 \\
\hline 8 & 0 & 45 & 0 & 10 & 0 & 55 & 0 & 15 \\
\hline 9 & 0 & 45 & 0 & 10 & -1 & 35 & -1 & 6 \\
\hline 10 & -1 & 25 & 0 & 10 & -1 & 35 & 0 & 15 \\
\hline 11 & 0 & 45 & 0 & 10 & 1 & 75 & -1 & 6 \\
\hline 12 & 1 & 65 & 0 & 10 & 1 & 75 & 0 & 15 \\
\hline 13 & 0 & 45 & -1 & 5 & -1 & 35 & 0 & 15 \\
\hline 14 & 0 & 45 & -1 & 5 & 1 & 75 & 0 & 15 \\
\hline 15 & 0 & 45 & 1 & 15 & 1 & 75 & 0 & 15 \\
\hline 16 & 0 & 45 & 1 & 15 & -1 & 35 & 0 & 15 \\
\hline 17 & 0 & 45 & 0 & 10 & 0 & 55 & 0 & 15 \\
\hline 18 & 1 & 65 & -1 & 5 & 0 & 55 & 0 & 15 \\
\hline 19 & 1 & 65 & 1 & 15 & 0 & 55 & 0 & 15 \\
\hline 20 & -1 & 25 & 0 & 10 & 1 & 75 & 0 & 15 \\
\hline 21 & 1 & 65 & 0 & 10 & -1 & 35 & 0 & 15 \\
\hline 22 & -1 & 25 & 0 & 10 & 0 & 55 & 1 & 24 \\
\hline 23 & 0 & 45 & 0 & 10 & -1 & 35 & 1 & 24 \\
\hline 24 & 0 & 45 & 0 & 10 & 1 & 75 & 1 & 24 \\
\hline 25 & 0 & 45 & -1 & 5 & 0 & 55 & 1 & 24 \\
\hline 26 & 0 & 45 & 1 & 15 & 0 & 55 & 1 & 24 \\
\hline 27 & 1 & 65 & 0 & 10 & 0 & 55 & 1 & 24 \\
\hline
\end{tabular}

For the Osmotic dehydration step, in a 1:4 weight-weight ratio, tomato slices are placed in a bath of water salted with commercial cooking salt $(\mathrm{NaCl})$ for 3 hours. The mixture is stirred manually every 10 minutes. Afterwards, the slices are drained for 3 minutes, and the excess of water was removed with clean dry laboratory tissues. Then, the slices were placed in the ventilated oven (air velocity $=13 \mathrm{~mm} \cdot \mathrm{s}^{-1}$ ), preheated at the defined temperature, for the desired time. Dried slices are removed from the oven and allowed to cool down in a desiccator before their weight and pictures was taken. Afterwards, they were grounded to a particle size less than $200 \mu \mathrm{m}$ and the physicochemical characterization of the powder was carried out. The powder obtained under optimal conditions were compared to fresh tomato and a local tomato powder, produce by local farmer by sun drying and purchased in the local market. The concentrates were prepared by adding dried tomato powder to water to reach 25\% DM [13], and underwent the same physicochemical characterization as the fresh tomato and the powders.

\section{Physicochemical Characterization}

The water content was determined according to the AOAC method [14].

The total carotenoid content is determined by modifying slightly the method described by [15] by using a mixture of $70 \%$ of petroleum ether and $30 \%$ Acetone.

The total titratable acidity is determined according to method of [16], and express as the equivalent mass (g) of citric acid per $100 \mathrm{~g}$ of dry mass of sample.
The swelling volume of the dry tomato powder was evaluated according to the method of Gould et al. [17].

The determination of the water retention capacity of the tomato powder was done according to the AACC method 5611 adapted by [18] and slightly modified. $1 \mathrm{~g}$ of powder $\left(\mathrm{M}_{0}\right)$ was mixed with $10 \mathrm{ml}$ of distilled water and mixture is stirred for 15 minutes, and then centrifuged at $2500 \mathrm{rpm}$ for $30 \mathrm{~min}$. The precipitate was weighed before $\left(\mathrm{M}_{1}\right)$ and after $\left(\mathrm{M}_{2}\right)$ drying at $105 \pm 2{ }^{\circ} \mathrm{C}$ for 24 hours. Apparent (WRCa) and real (WRCr) water absorption capacity are calculated using the following equations:

$W R C_{a}(\%)=\frac{M_{1}-M_{0}}{M_{0}} \times 100$

$W R C_{r}(\%)=\frac{M_{1}-M_{0}}{M_{2}} \times 100$

Image processing is done via ImageJ software using the RGB processing system in CIE Lab. The parameters measured were $L^{*}, a^{*}$ et $b^{*}$. Then they were used to calculate $\mathrm{C}, \mathrm{a}^{*} / \mathrm{b}^{*}$ et $\mathrm{H}^{\circ}$

$C^{*}=\sqrt{a^{* 2}+b^{* 2}}$

$H^{*}=\arctan \left(a^{*} / b^{*}\right)$

\section{Model Validation, Multi-criteria Optimization and} Statistical Analysis

Minitab 17® (1829 Pine Hall Rd, State College, PA 16801, USA) was used to generate the experimental design and analyse the results for modelling and optimization purpose. The developed models were validated using the determination coefficient $\left(\mathrm{R}^{2}\right)$, the adjusted determination coefficient $\left(\mathrm{R}^{2}{ }_{\text {adj }}\right)$, the absolute average deviation (AAD), the biais $\left(\mathrm{B}_{\mathrm{f}}\right)$ and precision $\left(\mathrm{A}_{\mathrm{f}}\right)$ factors according to the values presented in Table II.

$B_{f}=10^{\frac{1}{n} \sum_{i=1}^{n} \log \frac{y_{c a l}}{y_{\text {exp }}}}$

$\mathrm{A}_{f}=10^{\frac{1}{\mathrm{n}} \sum_{\mathrm{i}=1}^{\mathrm{n}} \mid\left(\log \frac{y_{\text {cal }}}{\mathrm{y}_{\text {exp }}}\right)}$

$\mathrm{AAD}=\frac{\sum_{\mathrm{i}=1}^{\mathrm{n}}\left|\left(\frac{y_{\exp }-y_{c a l}}{y_{\exp }}\right)\right|}{\mathrm{n}}$

with: $\mathrm{y}_{\exp }=$ experimental value; $\mathrm{y}_{\mathrm{cal}}=$ calculated value; " $\mathrm{i}, \mathrm{p}$ " represent the rank of the experiments and " $n$ " the total number of experiments.

\begin{tabular}{cc}
\hline \multicolumn{2}{c}{ TABLE II: MODEL VALIDATION INDICATORS } \\
\hline \hline $\mathrm{R}_{\text {adj }}$ & Validity range \\
$\mathrm{AAD}$ & $80 \%-100 \%[19]$ \\
$\mathrm{A}_{\mathrm{f}}$ and $\mathrm{B}_{\mathrm{f}}$ & $0-0.3[20]$ \\
\hline \hline
\end{tabular}

The ANOVA test allowed the identification of significant contributions $(\mathrm{P} \geq 0.05)$ of the varied parameters on the studied properties. In the present study, the optimization procedure aimed at finding the best compromise between the studied parameters in order to achieved specific product 
characteristics, presented in Table III.

Statistical analyses were performed with the Statgraphics Centurion XVI software version 16.1.18 using Fischer's least significant difference tests to compare means at the $5 \%$ significance level.

TABLE III: OPTIMIZATION AIM AND CONSTRAINTS

\begin{tabular}{ccc}
\hline \hline Constraints & Studied responses & Target values \\
\hline \multirow{2}{*}{ Maximize } & Carotenoids & Maximize \\
& $\mathrm{H}^{\circ}$ & ] $18^{\circ}-54^{\circ}[[22]$ \\
\hline Minimize & Water content & ] $8 \%-12 \%[[23]$ \\
\hline \hline
\end{tabular}

\section{RESULTS AND DISCUSSION}

The tomatoes fruits used for this study presented an average diameter of $5.01 \pm 0.3 \mathrm{~cm}$ and an average length of $6.2 \pm 0.5 \mathrm{~cm}$. Thus, they can be described as having an elongated form $\left(\mathrm{C}_{\mathrm{f}}=1.23\right)$.

\section{A. Modelling, Validation and Optimisation}

The results of the experiments are summarized in Table IV. The values of the parameters of the colour represent the means of the differences of the most saturated points of the least saturated points. Regular modelling did not provide second-degree quadratic equations able to describe, in a satisfactory manner, the relationship between the operating factors and the followed responses. Therefore, a change of variables (Box-Cox transformation) allowed the change of the presentation of the responses in order to link the studied factors and responses in a satisfactory manner through second degree quadratic equations postulated when using experimental design coupled to response surface methodology. That transformation was also done using MINITAB17. The coefficients of the models depicting the relationship between the studied parameters and the physicochemical properties of the dried tomatoes, with their corresponding probability representing their significance are summarized in Table $\mathrm{V}$, along with their model validation indicators. The $\lambda$ and $g$ represent respectively the power and geometric average of the responses. Despite an adjusted $\mathrm{R}^{2}$ less than $80 \%$, the models of luminance $(\mathrm{L})$ and the hue $\left(\mathrm{H}^{\circ}\right)$ can be considered valid since all their other validation indicators are good. The following equation are the models describing the relationship between the studied factors and the responses. $-(\text { Carotenoids })^{-\frac{1}{2}}=-0,1831+5.36 \times 10^{-3} X_{1}+1.494 \times 10^{-2} X_{2}-5 \times 10^{-5} X_{3}-6.99 \times 10^{-3} X_{4}-1.6 \times 10^{-5} X_{1}^{2}-1.88 \times 10^{-4} X_{2}^{2}+1.1 \times 10^{-5} X_{3}^{2}+$
$1.91 \times 10^{-4} X_{4}^{2}-2.23 \times 10^{-4} X_{1} X_{2}-3.2 \times 10^{-5} X_{1} X_{3}+6 \times 10^{-7} X_{1} X_{4}-2 \times 10^{-6} X_{2} X_{3}-2.4 \times 10^{-5} X_{2} X_{4}+3 \times 10^{-6} X_{3} X_{4}$

$-(\boldsymbol{R} \boldsymbol{W C})^{-1}=0.0662+7.4 \times 10^{-4} X_{1}+6.71 \times 10^{-3} X_{2}-2.76 \times 10^{-3} X_{3}-1.18 \times 10^{-2} X_{4}-4 \times 10^{-7} X_{1}^{2}-2.79 \times 10^{-4} X_{2}^{2}-0 X_{3}^{2}+1.4 \times 10^{-4} X_{4}^{2}-$

$9.8 \times 10^{-5} X_{1} X_{2}+4 \times 10^{-6} X_{1} X_{3}+2.4 \times 10^{-5} X_{1} X_{4}+7.5 \times 10^{-5} X_{2} X_{3}+1.87 \times 10^{-4} X_{2} X_{4}+4.7 \times 10^{-5} X_{3} X_{4}$

$\ln (\boldsymbol{L})=2.612-5.3 \times 10^{-3} X_{1}-5.63 \times 10^{-2} X_{2}+1.95 \times 10^{-2} X_{3}+1.76 \times 10^{-2} X_{4}+6.7 \times 10^{-5} X_{1}^{2}+2.2 \times 10^{-4} X_{2}^{2}-1.27 \times 10^{-4} X_{3}^{2}+5.46 \times 10^{-4} X_{4}^{2}-$

$8.61 \times 10^{-4} X_{1} X_{2}+2.61 \times 10^{-4} X_{1} X_{3}-5.2 \times 10^{-5} X_{1} X_{4}+6.05 \times 10^{-4} X_{2} X_{3}+4.79 \times 10^{-3} X_{2} X_{4}-1.218 \times 10^{-3} X_{3} X_{4}$

$\ln \left(\boldsymbol{a}^{*}\right)=-0,669+2.24 \times 10^{-2} X_{1}+0.169 X_{2}+7.58 \times 10^{-2} X_{3}+8.93 \times 10^{-2} X_{4}-1.06 \times 10^{-4} X_{1}^{2}-1.78 \times 10^{-3} X_{2}^{2}-5.66 \times 10^{-4} X_{3}^{2}-1.339 \times 10^{-3} X_{4}^{2}+$

$4.8 \times 10^{-5} X_{1} X_{2}-1.6 \times 10^{-5} X_{1} X_{3}-7.76 \times 10^{-4} X_{1} X_{4}-1.979 \times 10^{-3} X_{2} X_{3}-1.494 \times 10^{-3} X_{2} X_{4}-1.33 \times 10^{-4} X_{3} X_{4}$

$\frac{\left(b^{*}\right)^{(\lambda-1)}}{\lambda \times g^{(\lambda-1)}}=-7.6-5.7 \times 10^{-2} X_{1}-1.442 X_{2}+0.74 \times 10^{-2} X_{3}+2.3 \times 10^{-2} X_{4}+3.26 \times 10^{-3} X_{1}^{2}+3.04 \times 10^{-2} X_{2}^{2}-7.14 \times 10^{-3} X_{3}^{2}+2.43 \times 10^{-3} X_{4}^{2}-$

$1.153 \times 10^{-2} X_{1} X_{2}+4.5 \times 10^{-3} X_{1} X_{3}-1.773 \times 10^{-2} X_{1} X_{4}-2.53 \times 10^{-3} X_{2} X_{3}+8.97 \times 10^{-2} X_{2} X_{4}-5.31 \times 10^{-3} X_{3} X_{4}$

$\frac{C^{(\lambda-1)}}{\lambda \times g^{(\lambda-1)}}=-50.6+0.355 X_{1}+1.431 X_{2}+1.438 X_{3}+1,32 X_{4}+2.7 \times 10^{-4} X_{1}^{2}-1.16 \times 10^{-2} X_{2}^{2}-1.172 \times 10^{-2} X_{3}^{2}-1.892 \times 10^{-3} X_{4}^{2}-6 \times 10^{-3} X_{1} X_{2}+$

$2.46 \times 10^{-3} X_{1} X_{3}-2.382 \times 10^{-2} X_{1} X_{4}-2.647 \times 10^{-2} X_{2} X_{3}+3.8 \times 10^{-2} X_{2} X_{4}-3.78 \times 10^{-2} X_{3} X_{4}$

$(\boldsymbol{H})^{\frac{1}{2}}=12.15-4.44 \times 10^{-2} X_{1}-0.451 X_{2}-6.86 \times 10^{-2} X_{3}-0.1479 X_{4}+3.36 \times 10^{-4} X_{1}^{2}+6 \times 10^{-3} X_{2}^{2}+3.71 \times 10^{-4} X_{3}^{2}+2.51 \times 10^{-3} X_{4}^{2}-$

$7.2 \times 10^{-4} X_{1} X_{2}+4.19 \times 10^{-4} X_{1} X_{3}+3.75 \times 10^{-4} X_{1} X_{4}+3.72 \times 10^{-3} X_{2} X_{3}+9.4 \times 10^{-3} X_{2} X_{4}-4.55 \times 10^{-4} X_{3} X_{4}$ 
TABLEIV: EXPERIMENTAL (EXP.) AND PREDICTED (CAL.) RESPONSES FOR EACH EXPERIMENT, AND VALIDATIONS INDICATORS

\begin{tabular}{|c|c|c|c|c|c|c|c|c|c|c|c|c|c|c|}
\hline \multirow[t]{2}{*}{$\mathrm{N}^{\circ}$ run } & \multicolumn{2}{|c|}{$\begin{array}{c}\text { Carotenoids } \\
(\mathrm{x} 10-2 \mathrm{mg} / 100 \mathrm{~g} \mathrm{DM}) \\
\end{array}$} & \multicolumn{2}{|c|}{ Residual water content (\%) } & \multicolumn{2}{|c|}{$\mathrm{L}$} & \multicolumn{2}{|c|}{$a^{*}$} & \multicolumn{2}{|c|}{$\mathrm{b}^{*}$} & \multicolumn{2}{|c|}{ C } & \multicolumn{2}{|c|}{$\mathrm{H}^{\circ}$} \\
\hline & Exp. & Cal. & Exp. & Cal. & Exp. & Cal. & Exp. & Cal. & Exp. & Cal. & Exp. & Cal. & Exp. & Cal. \\
\hline 1 & 137.6 & 124.2 & 8.86 & 8.80 & 24.34 & 21.7 & 19.57 & 21.08 & 23.40 & 23.06 & 30.51 & 30.75 & 50.09 & 46.51 \\
\hline 2 & 528.4 & 672.5 & 14.28 & 17.46 & 33.70 & 29.78 & 20.10 & 21.80 & 24.63 & 23.80 & 31.79 & 32.23 & 50.79 & 46.13 \\
\hline 3 & 1511.9 & 921.1 & 33.09 & 22.56 & 20.87 & 23.37 & 20.41 & 18.80 & 21.00 & 20.41 & 29.28 & 27.07 & 45.81 & 46.35 \\
\hline 4 & 350.1 & 330.8 & 11.80 & 11.13 & 31.51 & 29.88 & 21.25 & 21.50 & 25.38 & 24.83 & 33.10 & 33.00 & 50.07 & 47.76 \\
\hline 5 & 228.8 & 253.7 & 16.67 & 18.59 & 22.22 & 24.08 & 23.04 & 21.22 & 18.22 & 20.42 & 29.37 & 29.37 & 38.34 & 42.82 \\
\hline 6 & 366.6 & 447.8 & 9.59 & 9.69 & 21.73 & 23.99 & 15.08 & 15.05 & 15.02 & 18.09 & 21.29 & 23.65 & 44.89 & 49.92 \\
\hline 7 & 3121.0 & 3653.7 & 44.51 & 64.53 & 19.55 & 17.73 & 20.44 & 21.32 & 17.82 & 19.07 & 27.12 & 29.33 & 41.10 & 40.84 \\
\hline 8 & 1150.5 & 1346.2 & 10.60 & 12.64 & 37.39 & 33.77 & 16.48 & 15.66 & 23.69 & 23.63 & 28.86 & 28.10 & 55.18 & 54.94 \\
\hline 9 & 588.0 & 711.3 & 15.55 & 14.40 & 35.88 & 34.49 & 17.33 & 19.34 & 19.80 & 19.32 & 26.31 & 27.89 & 48.81 & 46.13 \\
\hline 10 & 384.6 & 464.9 & 9.79 & 10.09 & 28.55 & 27.32 & 12.70 & 12.91 & 21.07 & 19.61 & 24.6 & 22.38 & 58.93 & 56.03 \\
\hline 11 & 453.7 & 389.9 & 13.09 & 13.95 & 23.15 & 23.51 & 17.52 & 17.38 & 20.27 & 20.66 & 26.79 & 26.71 & 49.17 & 48.96 \\
\hline 12 & 643.5 & 522.6 & 23.50 & 20.03 & 23.43 & 24.07 & 27.38 & 26.96 & 20.53 & 19.34 & 34.22 & 32.60 & 36.87 & 36.96 \\
\hline 13 & 345.3 & 277.6 & 7.41 & 7.50 & 25.55 & 25.58 & 17.98 & 18.08 & 22.20 & 23.38 & 28.57 & 29.90 & 50.99 & 50.54 \\
\hline 14 & 450.1 & 343.4 & 14.06 & 12.26 & 32.94 & 33.37 & 12.74 & 12.71 & 21.32 & 21.44 & 24.83 & 23.78 & 59.14 & 59.01 \\
\hline 15 & 471.2 & 800.1 & 16.36 & 15.59 & 29.77 & 29.87 & 18.96 & 20.05 & 28.58 & 27.78 & 34.29 & 34.14 & 56.44 & 54.94 \\
\hline 16 & 1222.0 & 1403.9 & 25.10 & 22.59 & 22.41 & 22.43 & 22.63 & 23.95 & 20.00 & 20.33 & 30.20 & 31.62 & 41.46 & 40.88 \\
\hline 17 & 320.7 & 353.3 & 8.47 & 8.47 & 21.76 & 24.34 & 22.06 & 19.84 & 20.26 & 19.92 & 29.95 & 28.52 & 42.56 & 46.29 \\
\hline 18 & 546.9 & 417.9 & 15.87 & 15.54 & 38.82 & 43.3 & 20.12 & 18.11 & 24.86 & 25.94 & 31.98 & 32.29 & 51.01 & 55.91 \\
\hline 19 & 419.2 & 372.5 & 13.08 & 12.97 & 25.94 & 27.58 & 23.74 & 23.75 & 21.97 & 23.43 & 32.34 & 33.33 & 42.77 & 44.47 \\
\hline 20 & 348.4 & 372.5 & 13.10 & 12.97 & 29.29 & 27.58 & 23.75 & 23.75 & 24.73 & 23.43 & 34.29 & 33.33 & 46.16 & 44.47 \\
\hline 21 & 355.7 & 372.5 & 12.75 & 12.97 & 27.62 & 27.58 & 23.75 & 23.75 & 23.35 & 23.43 & 33.3 & 33.33 & 44.51 & 44.47 \\
\hline 22 & 533.7 & 560.0 & 10.93 & 10.62 & 32.94 & 32.36 & 22.02 & 21.54 & 27.10 & 27.47 & 34.92 & 35.00 & 50.91 & 52.69 \\
\hline 23 & 121.0 & 154.4 & 11.40 & 13.00 & 32.32 & 31.48 & 23.04 & 22.70 & 25.19 & 25.17 & 34.14 & 34.41 & 47.55 & 48.18 \\
\hline 24 & 1860.4 & 966.4 & 19.10 & 18.88 & 27.56 & 29.91 & 26.20 & 25.64 & 27.70 & 28.3 & 38.13 & 37.73 & 46.59 & 48.54 \\
\hline 25 & 454.3 & 396.6 & 11.14 & 12.29 & 40.06 & 36.81 & 15.60 & 16.78 & 22.13 & 22.97 & 27.08 & 28.48 & 54.81 & 53.87 \\
\hline 26 & 851.8 & 831.3 & 19.48 & 17.63 & 24.19 & 24.53 & 23.24 & 22.17 & 22.43 & 21.06 & 32.30 & 31.25 & 43.99 & 42.28 \\
\hline 27 & 198.3 & 205.3 & 11.12 & 9.95 & 35.93 & 37.13 & 14.83 & 15.33 & 26.79 & 25.92 & 30.62 & 30.76 & 61.03 & 59.21 \\
\hline
\end{tabular}


TABLE V: MOdel PARAMETER COEFFICIENTS AND PROBABILITIES

\begin{tabular}{|c|c|c|c|c|c|c|c|c|c|c|c|c|c|c|}
\hline & \multicolumn{2}{|c|}{ Carotenoids } & \multicolumn{2}{|c|}{ Residual water content } & \multicolumn{2}{|l|}{$\mathrm{L}$} & \multicolumn{2}{|l|}{$\mathrm{a}^{*}$} & \multicolumn{2}{|c|}{$b^{*}$} & \multicolumn{2}{|c|}{$\mathrm{C}$} & \multicolumn{2}{|l|}{$\mathrm{H}^{\circ}$} \\
\hline & Coef. & $\mathrm{P}$ & Coef. & $\mathrm{P}$ & Coef. & $\mathrm{P}$ & Coef. & $\mathrm{P}$ & Coef. & $\mathrm{P}$ & Coef. & $\mathrm{P}$ & Coef. & $\mathrm{P}$ \\
\hline Constant & -0.1831 & 0.000 & 0.0662 & 0.000 & 2.612 & 0.000 & -0.669 & 0.000 & -7.6 & 0.000 & -50.6 & 0.000 & 12.15 & 0.000 \\
\hline $\mathrm{X}_{1}$ & $5.36 \times 10-3$ & 0.533 & $7.4 \times 10^{-4}$ & 0.987 & $-5.3 \times 10-3$ & 0.003 & $2.24 \times 10-2$ & 0.523 & $-5.7 \times 10-2$ & 0.000 & 0.355 & 0.001 & $-4.44 \times 10-2$ & 0.079 \\
\hline $\mathrm{X}_{2}$ & $1.494 \times 10-2$ & 0.161 & $6.71 \times 10^{-3}$ & 0.000 & $-5.63 \times 10-2$ & 0.035 & 0.169 & 0.382 & -1.442 & 0.115 & 1.431 & 0.654 & -0.451 & 0.282 \\
\hline $\mathrm{X}_{3}$ & $-5 \times 10-5$ & 0.043 & $-2.76 \times 10^{-3}$ & 0.000 & $1.95 \times 10-2$ & 0.005 & $7.58 \times 10-2$ & 0.000 & 0.74 & 0.030 & 1.438 & 0.018 & $-6.86 \times 10-2$ & 0.000 \\
\hline $\mathrm{X}_{4}$ & $-6.99 \times 10-3$ & 0.001 & $-1.18 \times 10^{-2}$ & 0.000 & $1.76 \times 10-2$ & 0.003 & $8.93 \times 10-2$ & 0.010 & $2.3 \times 10-2$ & 0.063 & 1.320 & 0.013 & -0.1479 & 0.148 \\
\hline $\mathrm{X}_{1}^{2}$ & $-1.6 \times 10-5$ & 0.079 & $-4 \times 10^{-7}$ & 0.759 & $6.7 \times 10-5$ & 0.569 & $-1.06 \times 10-4$ & 0.255 & $3.26 \times 10-3$ & 0.065 & $2.7 \times 10-4$ & 0.879 & $3.36 \times 10-4$ & 0.265 \\
\hline $\mathrm{X}_{2}^{2}$ & $-1.88 \times 10-4$ & 0.173 & $-2.79 \times 10^{-4}$ & 0.148 & $2.2 \times 10-4$ & 0.908 & $-1.78 \times 10-3$ & 0.236 & $3.04 \times 10-2$ & 0.260 & $-1.16 \times 10-2$ & 0.678 & $6 \times 10-3$ & 0.217 \\
\hline $\mathrm{X}_{3}^{2}$ & $1.1 \times 10-5$ & 0.198 & 0 & 0.987 & $-1.27 \times 10-4$ & 0.288 & $-5.66 \times 10-4$ & 0.000 & $-7.14 \times 10-3$ & 0.001 & $-1.172 \times 10-2$ & 0.000 & $3.71 \times 10-4$ & 0.222 \\
\hline $\mathrm{X}_{4}^{2}$ & $1.91 \times 10-4$ & 0.000 & $1.4 \times 10^{-4}$ & 0.027 & $5.46 \times 10-4$ & 0.350 & $-1.339 \times 10-3$ & 0.010 & $2.43 \times 10-3$ & 0.765 & $-1.892 \times 10-2$ & 0.045 & $2.51 \times 10-3$ & 0.103 \\
\hline $\mathrm{X}_{1} \mathrm{X}_{2}$ & $-2.23 \times 10-4$ & 0.000 & $-9.8 \times 10^{-5}$ & 0.085 & $-8.61 \times 10-4$ & 0.127 & $4.8 \times 10-5$ & 0.910 & $-1.153 \times 10-2$ & 0.146 & $-6 \times 10-3$ & 0.461 & $-7.2 \times 10-4$ & 0.596 \\
\hline $\mathrm{X}_{1} \mathrm{X}_{3}$ & $-3.2 \times 10-5$ & 0.006 & $4 \times 10^{-6}$ & 0.792 & $2.61 \times 10-4$ & 0.070 & $-1.6 \times 10-5$ & 0.881 & $4.5 \times 10-3$ & 0.032 & $2.46 \times 10-3$ & 0.237 & $4.19 \times 10-4$ & 0.231 \\
\hline $\mathrm{X}_{1} \mathrm{X}_{4}$ & $6 \times 10-7$ & 0.795 & $2.4 \times 10^{-5}$ & 0.428 & $-5.2 \times 10-5$ & 0.860 & $-7.76 \times 10-4$ & 0.005 & $-1.773 \times 10-2$ & 0.001 & $-2.382 \times 10-2$ & 0.000 & $3.75 \times 10-4$ & 0.621 \\
\hline $\mathrm{X}_{2} \mathrm{X}_{3}$ & $-2 \times 10-6$ & 0.956 & $7.5 \times 10^{-5}$ & 0.175 & $6.05 \times 10-4$ & 0.272 & $-1.979 \times 10-3$ & 0.000 & $-2.53 \times 10-3$ & 0.739 & $-2.647 \times 10-2$ & 0.006 & $3.72 \times 10-3$ & 0.016 \\
\hline $\mathrm{X}_{2} \mathrm{X}_{4}$ & $-2.4 \times 10-5$ & 0.775 & $1.87 \times 10^{-4}$ & 0.131 & $4.79 \times 10-3$ & 0.001 & $-1.494 \times 10-3$ & 0.128 & $8.97 \times 10-2$ & 0.000 & $3.8 \times 10-2$ & 0.051 & $9.4 \times 10-3$ & 0.008 \\
\hline \multirow[t]{2}{*}{$\mathrm{X}_{3} \mathrm{X}_{4}$} & $3 \times 10-6$ & 0.905 & $4.7 \times 10^{-5}$ & 0.128 & $-1.218 \times 10-3$ & 0.001 & $-1.33 \times 10-4$ & 0.571 & $-5.31 \times 10-3$ & 0.222 & $-3.78 \times 10-2$ & 0.405 & $-4.55 \times 10-4$ & 0.549 \\
\hline & & & & & & & & & $\lambda=4$ & $\mathrm{~g}=22.344$ & $\lambda=3$ & $\mathrm{~g}=30.138$ & & \\
\hline $\mathrm{R}^{2}(\%)$ & \multicolumn{2}{|c|}{90.90} & \multicolumn{2}{|c|}{93.03} & \multicolumn{2}{|l|}{88.35} & \multicolumn{2}{|l|}{92.52} & \multicolumn{2}{|c|}{0.92} & \multicolumn{2}{|c|}{92.06} & \multicolumn{2}{|l|}{84.03} \\
\hline $\mathrm{R}^{2}$ aj $(\%)$ & \multicolumn{2}{|c|}{80.29} & \multicolumn{2}{|c|}{84.90} & \multicolumn{2}{|l|}{74.75} & \multicolumn{2}{|l|}{83.79} & \multicolumn{2}{|c|}{0.82} & \multicolumn{2}{|c|}{82.79} & \multicolumn{2}{|l|}{65.40} \\
\hline AADM & \multicolumn{2}{|c|}{0.187} & \multicolumn{2}{|c|}{0.093} & \multicolumn{2}{|l|}{0.056} & \multicolumn{2}{|l|}{0.041} & \multicolumn{2}{|c|}{0.041} & \multicolumn{2}{|c|}{0.032} & \multicolumn{2}{|l|}{0.039} \\
\hline $\mathrm{B}_{\mathrm{f}}$ & \multicolumn{2}{|c|}{0.990} & 0.9 & & 0.999 & & 0.999 & & & & & & 1.000 & \\
\hline $\mathrm{A}_{\mathrm{f}}$ & 1.211 & & 1.0 & & 1.058 & & 1.042 & & & & & & 1.039 & \\
\hline
\end{tabular}




\section{B. Effect of Osmotic Dehydration and Drying on Carotenoids Content}

The drying temperature $\left(\mathrm{X}_{3}\right)$, the drying time $\left(\mathrm{X}_{4}\right)$ and its quadratic effect $\left(\mathrm{X}_{4}^{2}\right)$, the interactions of the osmotic dehydration with the salt concentration $\left(\mathrm{X}_{1} \mathrm{X}_{2}\right)$, and with the drying temperature $\left(\mathrm{X}_{1} \mathrm{X}_{3}\right)$, present a significant effect on the carotenoids content of the dried slices. They all contribute to the decrease of the carotenoids, except for the quadratic effect of the drying time $\left(\mathrm{X}_{4}{ }^{2}\right)$. As thermosensitive molecules, carotenoids are greatly affected by the temperature of the milieu during the processing, with higher temperature capable of inducing an important reduction of their amount in the final product, in comparison to the fresh sample. Therefore, as both osmotic dehydration and the drying involve heat treatment, the reduction of the carotenoids content by the significant operating conditions is quite expected. The opposite behaviour, induced by high drying temperature values $\left(\mathrm{X}_{4}^{2}\right)$, will be linked to the formation of a crust on the surface of the slices. This would then play a protective role for carotenoids which are less exposed during drying.

\section{Effect of Osmotic Dehydration and Drying on the Residual Water Content}

$\mathrm{NaCl}$ concentration $\left(\mathrm{X}_{2}\right)$ presents a significant positive effect on the RWC, while the drying temperature $\left(\mathrm{X}_{3}\right)$ has the opposite effect. The drying time $\left(\mathrm{X}_{4}\right)$ contributes also to the reduction of the RWC of the dried tomato slices, but its quadratics contribution $\left(\mathrm{X}_{4}^{2}\right)$, representing an excess of this parameter, has an opposite effect since it contributes to increase the RWC. During osmotic dehydration, the salt is absorbed on by the tomato slices, which lead to an increase of water retention of the tomato slices. Thus, for similar drying conditions, the residual water content will increase with the salt concentration. During the drying step, the increase in temperature promotes the water evaporation, and thus the reduction of the residual water content. But drying is also the cause of some thermal destruction of the tomato slices and the crystallisation of the salt absorbed. Both phenomena induce the reduction of the porosity of the slices, and the formation of crust, which reduce water evaporation.

\section{Effect of Osmotic Dehydration and Drying on Colour Parameters}

The luminance, $\mathrm{L}^{*}$, is a colour parameter which indicates the clarity of the sample. It varies from black (0) to white (100). The parameters $\mathrm{a}^{*}$ and $\mathrm{b}^{*}$ are chromatic coordinates of the colour, scaled from green $(<0)$ to red $(>0)$, and blue $(<0)$ to yellow $(>0)$ respectively. The saturation, $C^{*}$, defines the purity of a colour. As its value increase, the sample's colour is qualified as bright. The hue, $\mathrm{H}^{*}$, is scaled on a colour wheel: purple red at $0^{\circ}$, yellow at $90^{\circ}$, green-bluish at $180^{\circ}$, and blue at $270^{\circ}$.

\section{1) Luminance $(L)$}

All the direct effects of the studied parameters $\left(\mathrm{X}_{1}, \mathrm{X}_{2}, \mathrm{X}_{3}\right.$, $\mathrm{X}_{4}$ ) present a significant contribution to the lightness of the dry tomato slices, along with the interactions of the drying time with the salt concentration $\left(\mathrm{X}_{2} \mathrm{X}_{4}\right)$, and with the drying temperature $\left(\mathrm{X}_{3} \mathrm{X}_{4}\right)$. The osmotic dehydration parameters $\left(\mathrm{X}_{1}\right.$ and $\left.\mathrm{X}_{2}\right)$ and the interaction between the studied drying parameters $\left(\mathrm{X}_{3} \mathrm{X}_{4}\right)$ have a negative effect on the dried slices luminance, which means the increase of these factors value lead to a darker final product. The drying $\left(\mathrm{X}_{3}\right.$ and $\left.\mathrm{X}_{4}\right)$ and the interaction between the salt concentration and the drying time $\left(\mathrm{X}_{2} \mathrm{X}_{4}\right)$ have the opposite effect, leading to a brighter final product.

\section{2) Parameter $a^{*}$}

The variation of the parameter $\mathrm{a}^{*}$ is significantly affected by the oven drying $\left(\mathrm{X}_{3}, \mathrm{X}_{4}, \mathrm{X}_{3}^{2}\right.$, and $\left.\mathrm{X}_{4}^{2}\right)$, and the interactions Osmotic dehydration temperature - drying time $\left(\mathrm{X}_{1} \mathrm{X}_{4}\right)$, and $\mathrm{NaCl}$ concentration - drying temperature $\left(X_{2} X_{3}\right)$. Drying temperature and time present a positive effect on a while their excess and the significant interaction have a negative effect. The dried tomato slices tend to be redder as the drying conditions are higher, until the excessive exposure of the samples to high temperature and long drying time induce the opposite effect. This can be linked to the water removal, which is more important, along with the crust formation, both happening faster, as the samples are exposed to higher temperature and for longer time. Negative effect of the excess drying conditions and the significant interactions can be associate to their detrimental effect they have on carotenoids and lycopenes which are molecules responsible of the red colour of tomatoes. A compromise towards moderate drying conditions is highly recommended for the preservations of biological samples [3], [6].

\section{3) Parameter $b^{*}$}

The model components with a significant effect on the yellow-blue scale are, the osmotic dehydration temperature $\left(\mathrm{X}_{1}\right)$, the drying temperature $\left(\mathrm{X}_{3}, \mathrm{X}_{3}^{2}\right)$, and their interactions $\left(\mathrm{X}_{1} \mathrm{X}_{3}\right)$, interactions of the drying time with osmotic dehydration $\left(\mathrm{X}_{1} \mathrm{X}_{4}\right)$, and with $\mathrm{NaCl}$ concentration $\left(\mathrm{X}_{2} \mathrm{X}_{4}\right)$. As observed with the parameter $a^{*}$, the drying temperature $\left(X_{3}\right)$ tends to increase the $b^{*}$ parameter value, inducing dried sample to be more yellowish. But a counter effect of its quadratic contribution $\left(\mathrm{X}_{3}^{2}\right)$ tends to increase the blue colour. The osmotic dehydration temperature $\left(\mathrm{X}_{1}\right)$, and its interaction with the drying time $\left(\mathrm{X}_{1} \mathrm{X}_{4}\right)$, tends to increase the blue coloration on the dried samples, while the interactions Osmotic dehydration time-drying temperature $\left(\mathrm{X}_{1} \mathrm{X}_{3}\right)$ and $\mathrm{NaCl}$ concentration-drying time $\left(\mathrm{X}_{2} \mathrm{X}_{4}\right)$ contribute to have dried tomato slices more yellowish. According to [24] the more yellow the tomato is after drying, the greater the destruction of the carotenoids. Thus, a higher osmotic dehydration temperature and drying temperature may preserve the quality of the dried tomato slices.

\section{4) Saturation $(C)$}

The osmotic dehydration time $\left(\mathrm{X}_{1}\right)$, the oven drying $\left(\mathrm{X}_{2}\right.$, $\mathrm{X}_{3}, \mathrm{X}_{2}^{2}, \mathrm{X}_{3}^{2}$ ), and the interactions osmotic dehydration timedrying time $\left(\mathrm{X}_{1} \mathrm{X}_{4}\right)$, and $\mathrm{NaCl}$ concentration-drying temperature $\left(\mathrm{X}_{2} \mathrm{X}_{3}\right)$ affect significantly the colour saturation of the dried tomato slices. The osmotic dehydration time $\left(\mathrm{X}_{1}\right)$, and the oven drying direct effects $\left(\mathrm{X}_{2}, \mathrm{X}_{3}\right)$ present a positive contribution to the saturation while the others significant parameters have the opposite effect. The destruction, by the temperature and promote by the exposure time, of organic material and thermosensitive molecules as carotenoids explains the decrease of the saturation under the effect of excess drying. Moderate drying conditions time, allowing the preservations of sensitive molecules in tomatoes will also contribute to obtain good looking products. 
TABLE VI: CHARACTERISTICS OF THE FRESH TOMATO, THE TOMATO POWDERS AND THE RECONSTITUTED TOMATO CONCENTRATES

\begin{tabular}{|c|c|c|c|c|}
\hline & \multirow{2}{*}{ Fresh tomato } & \multicolumn{2}{|c|}{ Tomato Powder } & \multirow{2}{*}{$\begin{array}{l}\text { Reconstituted tomato } \\
\text { concentrates } \\
\text { from tomato powder dried } \\
\text { under optimal conditions }\end{array}$} \\
\hline & & $\begin{array}{c}\text { Experimental optimal } \\
\text { conditions }\end{array}$ & $\begin{array}{l}\text { From local } \\
\text { production }\end{array}$ & \\
\hline Dry matter $(\%)$ & $5.37 \pm 0.62^{c}$ & $90.02 \pm 1.30^{\mathrm{a}}$ & $71.74 \pm 1.57^{b}$ & 25 \\
\hline Titratable acidity $(\mathrm{g} / 100 \mathrm{~g})$ & $37.5 \pm 1.50^{\mathrm{a}}$ & $37.5 \pm 2.50^{\mathrm{a}}$ & $38.5 \pm 1.50^{\mathrm{a}}$ & $37.5 \pm 2.50^{\mathrm{a}}$ \\
\hline $\mathrm{pH}$ & $4.10 \pm 0.22^{\mathrm{a}}$ & $4.00 \pm 0.50^{\mathrm{a}}$ & $4.10 \pm 0.75^{\mathrm{a}}$ & $3.97 \pm 0.45^{\mathrm{a}}$ \\
\hline Carotenoids (mg/100g DM) & $25.00 \pm 0.50^{\mathrm{a}}$ & $18.44 \pm 1.50^{\mathrm{b}}$ & $11.89 \pm 0.56^{\mathrm{c}}$ & $18.44 \pm 1.50^{b}$ \\
\hline $\mathrm{L}$ & $32.00 \pm 2.50^{\mathrm{b}}$ & $40.69 \pm 2.80^{\mathrm{a}}$ & $13.28 \pm 1.96^{\mathrm{d}}$ & $21.96 \pm 1.50^{\mathrm{c}}$ \\
\hline$a^{*}$ & $38.00 \pm 1.50^{\mathrm{a}}$ & $17.16 \pm 1.30^{\mathrm{b}}$ & $7.85 \pm 1.00^{\mathrm{c}}$ & $16.89 \pm 2.53^{b}$ \\
\hline$b^{*}$ & $29.00 \pm 1.45^{\mathrm{b}}$ & $35.98 \pm 1.70^{\mathrm{a}}$ & $11.13 \pm 0.83^{\mathrm{d}}$ & $20.15 \pm 1.70^{\mathrm{c}}$ \\
\hline $\mathrm{C}$ & $48.55 \pm 1.33^{\mathrm{a}}$ & $39.86 \pm 2.80^{\mathrm{b}}$ & $13.62 \pm 1.54^{\mathrm{d}}$ & $26.29 \pm 1.50^{\mathrm{c}}$ \\
\hline $\mathrm{H}^{\circ}$ & $37.06 \pm 2.55^{\mathrm{c}}$ & $64.50 \pm 3.60^{\mathrm{a}}$ & $54.79 \pm 3.50^{\mathrm{b}}$ & $50.04 \pm 2.55^{b}$ \\
\hline WRCa (\%) & - & $172.50 \pm 2.50^{\mathrm{a}}$ & $145.00 \pm 5.58^{b}$ & - \\
\hline WRCr $(\%)$ & - & $616.07 \pm 3.50^{\mathrm{a}}$ & $310.42 \pm 4.53^{b}$ & - \\
\hline $\begin{array}{c}\text { Swelling volume }(\mathrm{mL} / \mathrm{g} \\
\mathrm{DM})\end{array}$ & - & $3.50 \pm 1.00^{\mathrm{a}}$ & $2.1 \pm 0.75^{b}$ & - \\
\hline
\end{tabular}

Values of powders and concentrates with different superscript letters are significantly different $(\mathrm{p}<0.05)$.

5) The hue $H^{\circ}$

The hue of the dried tomato slices colour is significantly affected by the during temperature $\left(\mathrm{X}_{3}\right)$, and the interactions between the $\mathrm{NaCl}$ concentration with the drying temperature $\left(\mathrm{X}_{2} \mathrm{X}_{3}\right)$ and with the drying time $\left(\mathrm{X}_{2} \mathrm{X}_{4}\right)$. The drying temperature present a negative effect on the dried tomato slice hue, while the interactions between the $\mathrm{NaCl}$ concentration and the drying parameters exhibit the opposite effect. The formation of the crust during the drying can be the reason of the positive contribution.

\section{E. Osmotic Dehydration - Drying Optimisation, Tomato Paste Reconstitution and Characterization}

The optimal conditions of the coupling of Osmotic dehydration and drying, using the multi-response approach, are: $65^{\circ} \mathrm{C}$ for the brine temperature $\left(\mathrm{T}_{\mathrm{OD}}\right), 5 \%$ of $\mathrm{NaCl}\left(\mathrm{C}_{\mathrm{NaCl}}\right)$, $43.88^{\circ} \mathrm{C}$ for the drying temperature $\left(\mathrm{T}_{\mathrm{Dry}}\right)$, and 24 hours of drying time (t). These results are similar to other authors finding, with $60^{\circ} \mathrm{C}$ and $5 \%$ of salt for the osmotic dehydration [6], and $44^{\circ} \mathrm{C}$ and about 7 hours of drying time [2]. This difference in drying time can be explain by a higher hot air velocity $\left(130 \mathrm{~m} . \mathrm{s}^{-1}\right)$ during their drying.

Table VI presents some physicochemical characteristics of the fresh tomato, tomato powders obtained under optimal osmotic dehydration-drying conditions, tomato powders locally produced by farmers, and a tomato concentrate prepared using the tomato powders obtained under experimental optimal conditions. The characteristics of the reconstituted tomato concentrate does not differ much from the powder from which it is prepared, except for color parameters. The optimal powder is significantly the lightest, compared to its parameter $\mathrm{L}$, and local powder the darkest amongst all samples.

Despite presenting a lower dry matter, the local tomato powder present similar $\mathrm{pH}$ and titratable acidity to the powder we obtained and the fresh tomato. But the optimal powder showed a very high swelling volume and water retention capacity demonstrating the preservation of the tomato structure. The value of the fresh tomato colour characteristics of are, globally, higher than the other product presented, but osmotic dehydration process allow to preserve carotenoids and colors [6], [7], explaining the difference between local and optimal powders.

\section{CONCLUSION}

This work contributes to find optimal conditions to have a best product as possible with affordable process such as osmotic dehydration joint to hot air drying process. A tomato powder obtained present a good quality compared to powder using a sun drying process which is uncontrolled.

\section{ACKNOWLEDGMENT}

The authors are grateful to the "Laboratoire Génie et Technologie Alimentaire (LAGETA)" and "Laboratoire Energie Signal Images et Automatique (LESIA)" of National School of Agro-Industrial Sciences (ENSAI) of the University of Ngaoundere for providing laboratory facilities.

\section{REFERENCES}

[1] R. Ndjouenkeu, “Opportunité d'amélioration de la qualité de la poudre de tomate pour couplage entre la déshydratation osmotique et le séchage," in Savanes africaines : des espaces en mutation, des acteurs face à de nouveaux défis. Actes du colloque, mai 2002, Garoua, Cameroun. Prasac, N'Djamena, Tchad-Cirad, Montpellier, France. Opportunité, 2003, p. 5p

[2] E. E. Abano, H. Ma, and W. Qu, "Optimization of drying conditions for quality dried tomato slices using response surface methodology," vol. 38, pp. 996-1009, 2014, doi: 10.1111/jfpp.12056.

[3] N. Lahmari and D. F. I. Azani, "Influence des méthodes de séchage sur la qualité des tomates séchées ( variété Zahra )," vol. 15, pp. 285-295, 2012.

[4] Y. Jiokap Nono, M. Reynes, N. Zakhia, A. L. Raoult-Wack, and F. Giroux, "Mise au point d'un procédé combiné de déshydratation imprégnation par immersion et séchage de bananes (Musa acuminata groupe Cavendish)," J. Food Eng., vol. 55, no. 3, pp. 231-236, 2002, doi: 10.1016/S0260-8774(02)00080-8.

[5] A. Kamińska, P. P. Lewicki, and P. Malczyk, "Mass transfer in osmotically dehydrated apple stored at temperatures above zero," $J$. Food Eng., vol. 86, no. 1, pp. 140-149, 2008, doi: 10.1016/j.jfoodeng.2007.09.020.

[6] J. S. Souza, M. F. D. Medeiros, M. M. A. Magalha, S. Rodrigues, and F. A. N. Fernandes, "Optimization of osmotic dehydration of tomatoes in a ternary system followed by air-drying," vol. 83, pp. 501-509, 2007, doi: 10.1016/j.jfoodeng.2007.03.038.

[7] P. Pani, A. Avitabile, M. Riva, A. Maestrelli, and D. Torreggiani, "Influence of an osmotic pre-treatment on structure-property 
relationships of air-dehydrated tomato slices," vol. 86, pp. 105-112 2008, doi: 10.1016/j.jfoodeng.2007.09.017.

[8] A. M. Goula, T. D. Karapantsios, D. S. Achilias, and K. G. Adamopoulos, "Water sorption isotherms and glass transition temperature of spray dried tomato pulp," J. Food Eng., vol. 85, no. 1, pp. 73-83, 2008, doi: 10.1016/j.jfoodeng.2007.07.015.

[9] A. Ferradji, F. S. A. Chaouche, D. Belhachat, and A. Malek, "Optimization of osmotic dehydration of tomatoes slices in salt and sucrose solutions using response surface methodology," vol. 18, pp. 539-549, 2015.

[10] C. V. P. Tsamo, A. F. Bilame, R. Ndjouenkeu, and Y. J. Nono, "Study of material transfer during osmotic dehydration of onion slices (Allium cepa) and tomato fruits (Lycopersicon esculentum)," LWT - Food Sci. Technol., vol. 38, no. 5, pp. 495-500, 2005, doi: 10.1016/j.lwt.2004.07.015.

[11] M. Agassounon Djikpo Tchibozo, S. Gomez, F. Tchobo, M. Soumanou, and F. Toukourou, "Essai de conservation de la tomate par la technique de la déshydratation imprégnation par immersion (DII)," Int. J. Biol. Chem. Sci., vol. 6, no. 2, pp. 657-669, 2012, doi: 10.4314/ijbcs.v6i2.10.

[12] S. L. C. Ferreira et al., "Box-Behnken design : An alternative for the optimization of analytical methods," vol. 597, pp. 179-186, 2007, doi 10.1016/j.aca.2007.07.011.

[13] Codex Stan, "La dénomination « concentré de tomates traité » désigne le produit: (a) préparé par concentration du liquide 1 , ou de la pulpe, extrait de tomates substantiellement saines, mûres et rouges (," pp. 16, 2013.

[14] AOAC (Association of Official Agricultural Chemists), Official methods of analyses, 15th ed. Washington, DC, 1990.

[15] J. Wolff, Manuel d'analyse des corps gras. Paris (France): Azoulay éd., 1968.

[16] AFNOR (Association Française de Normalisation), Recueil des normes françaises des produits dérivés des fruits et légumes. Jus de fruits., lére éditi. 1982.

[17] J. M. Gould, B. K. Jasberg, L. . Dexter, J. T. Hsu, S. M. Lewis, and J. R. Fahey, "High-fibre, Noncalorie flour substitute for baked foods. Effect of alkaline peroxide-treated lignolcellulose on dough properties," Cereal Chem., vol. 66, no. 3, pp. 201-205, 1989.

[18] A. D. Bettge, C. F. Morris, V. L. DeMacon, and K. K. Kidwell, "Adaptation of AACC Method 56-11, solvent retention capacity, for use as an early generation selection tool for cultivar development," Cereal Chem., vol. 79, no. 5, pp. 670-674, 2002, doi: 10.1094/CCHEM.2002.79.5.670.

[19] A. M. Joglekar and A. T. May, "Product Excellence through Design of Experiments," Cereal Foods World, vol. 32, pp. 857-868, 1987.

[20] D. Baş and I. H. Boyaci, "Modeling and optimization i: Usability of response surface methodology," J. Food Eng., vol. 78, no. 3, pp. 836845, 2007, doi: 10.1016/j.jfoodeng.2005.11.024

[21] P. Dalgaard and L. Vigel Jørgensen, "Predicted and observed growth of Listeria monocytogenes in seafood challenge tests and in naturally contaminated cold-smoked salmon," Int. J. Food Microbiol., vol. 40 no. 1-2, pp. 105-115, 1998, doi: 10.1016/S0168-1605(98)00019-1.

[22] Konica Minolta, “Analyse des couleurs, parlons clair," The essentials of imaging, p. 46p, 2003.
[23] CEE-ONU, "Norme CEE-ONU (Commission Economique des Nations Unies pour L'Europe) DDP-19 concernant la commercialisation et le contrôle de la qualité commerciale des tomates séchées.," p. 8p, 2007.

[24] K. Kone, Amélioration de la qualité de la tomate séchée par microondes assistés par air chaud avec pilotage de la puissance spécifique Kisselmina Kone To cite this version: HAL Id: pastel 00771870 L 'Institut des Sciences et Industries du Vivant et de l 'Envir. 2013.

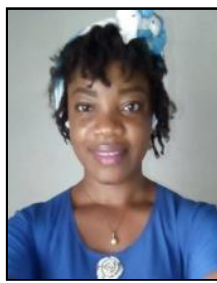

C. T. Maka, Ph.D in Chemical Engineering applied to Food. Presently, Full Research Assistant and Lecturer at the Department of Process Engineering of National School of Agro-Industrial Sciences (ENSAI) of University of Ngaoundere, P.O Box 455 Ngaoundere, Cameroon.

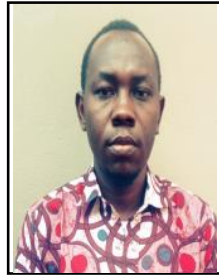

O. R. Isma-ila, Agro-food Engineer (M. Eng.) at the Department of Process Engineering of National School of Agro-Industrial Sciences (ENSAI) of University of Ngaoundere, P.O Box 455 Ngaoundere, Cameroon

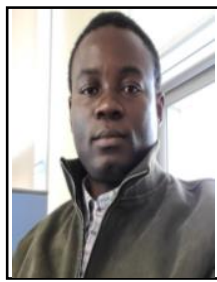

F. J. Ekorong Akouan Anta, Agro-food Engineer (M. Eng.) since 2011, MSc. in Food Process Engineering since 2012. Presently, Research Assistant at the Department of Environmental Technology, Food Technology, and molecular Biotechnology, Ghent University Global Campus, Incheon, South Korea, 119 Songdomunhwa-ro, Yeonsu-gu, Incheon 21985, Republic of Korea.

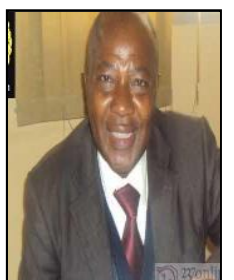

C. Kapseu, Full Professor at the Department of Process Engineering of National School of AgroIndustrial Sciences (ENSAI) of University of Ngaoundere, P.O Box 455 Ngaoundere, Cameroon. Coordinator of Alumni Scholarship holders of the University of Ngaoundéré; Officer of the Cameroonian Order of Merit, Engineer and French-speaking expert, Medalist Chevreuil (Paris, France), Associate Professor INPL (France) of the TWAS scholarship.
ATLAS / AAI (USA) alumniAward, Ambassador 